\title{
BYZANTIUM AND THE END OF THE MIDDLE AGES*
}

\author{
JOHN MONFASANI \\ UNIVERSITY AT ALBANY - SUNY
}

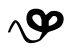

Byzantinists have a great advantage over their counterparts in other historical fields; they know exactly the moment when their subject terminated: 29 May 1453. But the end of Byzantium was not the end of the Greek Middle Ages, let alone the end of the Middle Ages tout court. I myself have been arguing now for years that the Renaissance was not the beginning of modern times but the final and, if you wish, culminating phase of the Middle Ages. ${ }^{1}$ The Reformation was the third and, in effect, the final medieval reformation. ${ }^{2}$ Conversely, the eighteenthcentury Enlightenment, not the Renaissance, should be labeled early modern, with the transition from medieval to early modern starting about the midseventeenth century and the term 'modern' without qualification being appropriate really only from about the turn of the nineteenth century forward. The historiography of Byzantine studies is a nice test case of these propositions.

Obviously Greeks and non-Greeks on the day after the Halosis, 30 May 1453, were as medieval in their world view, historical perspective, technological conditions, and so forth as they had been the day before. So the question becomes: when, at least as far as Byzantine studies are concerned, did Byzantine studies, as such studies are understood today, begin. The traditional answer has been the mid-seventeenth century, with the appearance of the first volumes of

* This essay was originally delivered as a paper at Harvard University on 27 October 2017 as part of a conference on Byzantine historiography.

1 John Monfasani, "The Renaissance as the Concluding Phase of the Middle Ages ", Bullettino dell'Istituto Storico Italiano per il Medio Evo, 108 (2006), p. 165-185; reprinted as Essay I in ID., Renaissance Humanism, from the Middle Ages to Modern Times, Ashgate-Variorum, Farnham-Surrey 2015 (Variorum Collected Studies Series, 1057).

2 The first was the Monastic Reformation of eleventh century; the second was the Mendicant Reformation of the thirteenth century; see Ibid., p. 179-180.
\end{abstract}


the Parisian corpus of Byzantine historians, with Du Cange's Glossarium ad scriptores mediae et infimae Graecitatis and his Historia Byzantina duplici commentario illustrata, with Leone Allacci's voluminous books on Byzantine theology, liturgy, popular religion, and religious architecture, with Jacques Goar's Euchologion sive Rituale Graecorum, and with publications by such luminaries as Philippe Labbe, Denis Petau, and François Combefis, ${ }^{3}$ to name just some of the greats of the age.

Agostino Pertusi has already taught us that the sixteenth-century humanist literature on Byzantium was really an extension of medieval interests and approaches, including the most notable product of that literature, Hieronymus Wolf's Byzantinae Historiae Corpus, produced with the help of Wilhelm Holtzmann (a.k.a. Xylander) and the patronage of Anton Fugger. ${ }^{4}$ Wolf's Byzantinae Historiae Corpus, just like other sixteenth-century editions of Byzantine works put out by Protestant scholars, and just like Catholic editions published by Jesuits and other Catholic scholars, emanated from religious interests in the conversion of the Orthodox to Protestantism or Roman Catholicism, or from a desire to provide object lessons for the Christian West of how internal divisions would invariably lead to conquest by the fearsome and ever threatening Turkish Sultanate. ${ }^{5}$ In other words, interests in Byzantine history and texts very much reflected internal Latin religious imperatives and political fears, just as was true in the medieval West up to the sixteenth century. The famous 1584 Turcograecia of the long time professor in Protestant Tübingen, Martin Crusius, fits perfectly into this mold since, as its subtitle and preface state, the work aims to reveal the miserable condition of the Christian Greeks now that they have fallen under the yoke of the Infidel Turk. ${ }^{6}$ Consequently, the back story of Renaissance editions of

3 For Du Cange, see Jürgen Leonhardt, « DuCange, Charles du Fresne », in Peter Kuhlmann, Helmuth SCHNEIDER (eds.), History of Classical Scholarship: a Biographical Dictionary, trans. and ed. DunCAN SMART, ChAD M. Schroeder, Brill, Leiden 2014, p. 166-167. There is no synthetic study of Labbe, but see HENRI OMONT, « La collections byzantine de Labbe et le projet de J.-M. Suarès », Revue des études grecques, 17 (1980), p. 18-32; on Petau, see Michael Hofmann, Theologie, Dogma und Dogmenentwicklung im theologischen Werk Denis Petau's. Mit einem biographischen und einem bibliographischen Anhang, Peter Lang, Bern 1976 (Regensburger Studien zur Theologie, 1); on Combefis, see Raymond Darricau, «A Hellenist of the Grand Siècle: The Dominican François Combefis (1605-1679) », Res Publica Litteraria, 1 (1978), p. 21-41.

4 Agostino Pertusi, Storiografia umanistica e mondo bizantino, Bruno Lavagnini, Palermo 1962, (Istituto siciliano di studi bizantini e neoellenici. Quaderni, 3), p. 45-66.

5 Ibid., p. 40-45 and 67-93.

6 MaRTIN CRUSIUS. Turcograeciae libri octo quibus Graecorum status sub imperio Turcico in Politia et Ecclesia, Oeconomia et Scholis, iam inde ab amissa Constantinopoli ad haec usque tempora luculenter describitur, per Leonardum Ostenium, Sebastiani Henricpetri impensa, Basileae 1584. See sign. $*_{2} \mathrm{v}$ of the preface: «Inscriptionem eis [sc. libris] feci TuRCOGRAECIAE propterea quod res Graecorum, iam inde ab Imperii Graeci amissione sub Turcico dominatu factas et fieri solitas

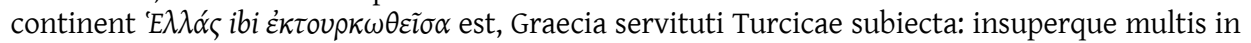
Religione erroribus et superstitionibus (quod initio nos latebat) obnoxia: ideoque merito infelicitas eius deploranda ». 
Byzantine texts accords very nicely with the notion that the Renaissance should be viewed as the final phase of the Middle Ages.

But what about the seventeenth-century explosion of brilliant scholarship on Byzantium? As I acknowledged earlier, the move from medieval to modern began somewhere in the seventeenth century. So by logical necessity, I would have to acknowledge that seventeenth-century scholarship on Byzantium was in some sense modern. But in what sense and why? The Parisian Corpus of Byzantine historians and Du Cange's Historia Byzantina and Glossarium established Byzantium as a distinct field of study and laid the foundation of scholarship that still serves the field today. It was not purely coincidental that prolific seventeenth-century textbook writer, Christopher Cellarius, published in 1688 a Historia Medii Aevi, canonizing a long developing view that historicized the Middle Ages and set it off from what he and contemporaries viewed as antiquity on one side and modernity on the other. ${ }^{7}$ What one may view as extraordinary about Cellarius's definition of the Middle Ages is that in chronological terms he essentially defined it as equivalent to the rise and fall of Byzantium. The full title of his textbook runs: Historia Medii Aevi a temporibus Constantini Magni ad Constantinopolim a Turcis captam deducta. Fittingly, he ended his narrative by explaining how Byzantine scholars such as Cardinal Bessarion, Theodore Gaza, and George of Trebizond came to Italy and joined forces with scholars such as Lorenzo Valla and Giovanni Pico della Mirandola to combat the medieval barbarism of the West, ${ }^{8}$ thus setting up the background for his next volume, the Historia Nova, hoc est XVI et XVII saeculorum. ${ }^{9}$

But if Byzantium as a field of study took its start in one sense in the seventeenth century, in another it remained an appendage to other fields and interests. The titles of Du Cange's two epoch-making Glossaria are very clear in their general classicist perspective, explaining that they are dictionaries of media et infima Latinitas and Graecitas. ${ }^{10}$ In the introduction to his Latin dictionary, Du Cange spent most of his time expostulating on the various forms of Late Latin barbarisms, offering in their defense chapters explaining that books written in a rudior stylus should not be viewed with contempt (contemnendi) if they offer something useful (siquid utilitatis), and arguing that not everything produced by the scriptores mediae aetatis was inutilia. ${ }^{11}$ But it was especially in the introduction

7 Wallace K. Ferguson, The Renaissance in Historical Thought: Five Centuries of Interpretation, Houghton Mifflin, Cambridge, MA 1948, p. 73-77.

8 Christophorus Cellarius. Historia Medii Aevi a temporibus Constantini Magni ad Constantinopolim a Turcis captam deducta, I. Bielkii, Jena 1688, p. 213-214.

Jena, 1696.

10 Glossarium Mediae et Infimae Latinitatis, G. Martini, Paris 1678; Glossarium ad Scriptores Mediae et Infimae Graecitatis, apud Anissonius, J. Postel, C. Rigaud, Lyon 1688.

11 After tracing the history of the Latin language and discussing the various dictionaries he used, he offer a chapter (LXI) with the title "Rudiori stylo scripti libri non contemnendi si quid utilitatis habeant aliunde »; and another (LXII) with the title " Non omnia sunt apud scriptores 
to his Greek dictionary that Du Cange gave full vent to his classicist prejudice, endorsing the view of the sixteenth-century Greek scholar Theodosius Zygomalas that among the myriad contemporary Greek dialects none is worse or more corrupt (deterior ac corruptior) than the Athenian, which is scarcely understood by other Greeks. The unstated premise undergirding Du Cange's and Zygomalas's opinion was that every declension from classical Greek is one more step towards decadence and corruption. ${ }^{12}$ The central fact about the great seventeenthcentury Byzantinists is that they were at heart classicists or patristic scholars or antiquarians or ardent proponents of some cause, be that cause French glory (not for nothing did Du Cange write a Histoire de l'empire de Constantinople sous les empereurs français $)^{13}$ or, be the cause, as was the case with Leone Allacci, the union between the Catholic and Orthodox Churches. As Karen Hartnup comments in respect to Allacci's treatise on Greek folk practices, «for Allatios the unbroken Orthodox tradition was alive and well in his own time». She concludes that Allacci effectively did not recognize "a 'Byzantine history', separated from the classical and Ottoman periods $» .^{14}$ Allacci's long Greek poem Hellas to the French crown fits perfectly within the long tradition since the fifteenth century of Greek émigrés issuing appeals for a crusade to rescue Greece from the oppressive rule of the Turks. ${ }^{15}$ In his insightful Storiografia umanistica e mondo bizantino, Agostino Pertusi stressed as the chief cause of seventeenth-century Byzantine scholarship what he call the "vasto movimento intellettuale e scientifico » of the age. ${ }^{16}$

But granting all of this, I think another factor should be added, namely, the contemporary political threat of the Ottoman Empire. With more scholarly tools and a larger educated audience than ever before, the seventeenth century could indulge to an extraordinary extent its interest in the collapse of the Byzantine Empire and the rise of the Ottoman. A telling indicator of these external influences is the well known eighteenth-century flip, indeed, revolution, in Byzantine studies, when the great advances in the field, with some exceptions, ${ }^{17}$ simply stopped. The reason for this transformation is usually attributed to the

mediae aetatis inutilia ». I used the edition of Paris 1840-1850, I, p. 39-41.

12 Preface to the 1688 edition, I, p. viII.

13 On the nationalistic French orientation of Du Cange's projects, see JEAN-Michel SPIESER, « Du Cange and Byzantium ", in Robin Cormack, ElizABETH Jeffreys (eds.), Through the Looking Glass: Byzantium through British Eyes. Papers from the Twenty-eight Spring Symposium of Byzantine Studies, London, March 1995, Ashgate, Aldershot 2000 (Society for the Promotion of Byzantine Studies. Publications, 7), p. 199-200.

14 Karen Hartnup, 'On the Beliefs of the Greeks': Leo Allatius and Popular Orthodoxy, Brill, Leiden 2004 (The Medieval Mediterranean. Peoples, Economies and Cultures, 400-1500, 54), p. 323.

15 See Vincenzo Rutolo, Il carme 'Hellas' di Leone Allacci, Bruno Lavagnini, Palermo 1966 (Istituto siciliano di studi bizantini e neoellenici. Quaderni, 3).

16 PeRTUSI, Storiografia umanistica e mondo bizantino, p. 90.

17 One thinks of the 22 tomes of CHARLES LE BEAU's (1701-1778) Histoire du Bas-Empire en commençant à Constantin le Grand, chez Desaint et Saillant, Paris 1756-1779. 
Enlightenment's disdain for all things medieval. But I suggest we should consider the effect of the Battle of Zenta in 1697 and the subsequent Peace of Karolwitz in 1699. The battle did not end the Ottoman threat, but its subsequent peace pretty much ended a thousand years of Moslem expansion against the Christian West and marked the beginning of the reverse process all the way into the twentieth century. In the eighteenth century, the Ottoman Empire ceased to be a threat and became itself a target for piecemeal conquest, in short, an object of benign consideration. Some years ago Bernard Lewis noted that

the eighteenth-century Enlightenment had two ideal prototypes, the noble savage and the wise and urban Oriental [...] For a while the Chinese held up as a model of virtue [...] Then disillusionment set in [...] shaped by [...] experience. By the time Gibbon began to write, there was a vacancy for an Oriental myth. Islam was in many ways suitable. While it was ceasing to impress, Islam no longer terrified. ${ }^{18}$

Consequently, one finds Edward Gibbon in chapter 50 of the Rise and Fall praising Mohammed as 'sagacious' and 'discerning' and speaking of his 'liberality'. As Lewis goes on to say,

[Islam] served as an admirable vehicle for anti-religious and anti-Christian polemic. Gibbon occasionally accomplishes this purpose by attacking Islam while meaning Christianity, more frequently by praising Islam as an oblique criticism of Christian usage, beliefs, and practice. ${ }^{19}$

Conversely - and most famously - Gibbon buried Byzantium in opprobrium, declaring at the start of his chapter 48:

At every step as we sink deeper into the decline and fall of the Eastern empire, the annals of each succeeding reign would impose a more ungrateful and melancholy task. These annals must continue to repeat a tedious and uniform tale of weakness and misery. ${ }^{20}$

And in chapter 53 he lamented that « [t]he minds of the Greeks were bound in the fetters of a base and imperious superstition $» .{ }^{21}$ Steven Runciman, having judged chapter 48 on Byzantium of the Decline and Fall « the weakest section of the whole work $»,{ }^{22}$ decided that «[t]he splendor of [Gibbon's] style and wit of his satire

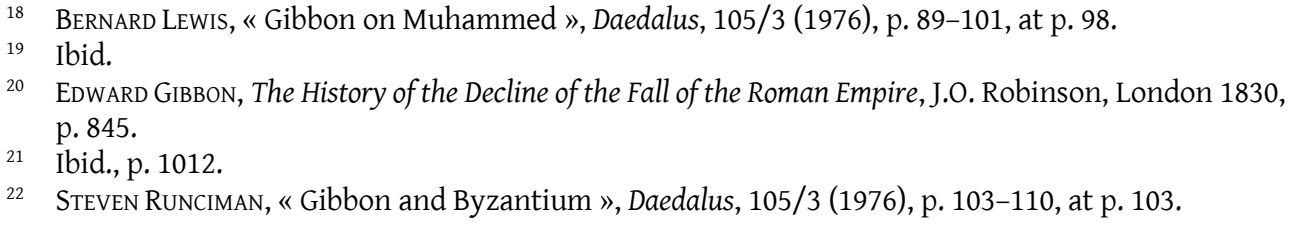


killed Byzantine studies for nearly a century $»{ }^{23}$ Consequently, if part of the transformation of Byzantine studies in the eighteenth century reflects the effect of the political and military revolution launched by the Battle of Zenta in 1697, then Prince Eugene of Savoy, the victor of Zenta, needs to be considered a decisive figure in the history of Byzantine studies.

Other factors intervened as well. The great competition between Protestants and Catholics to win Greek Orthodoxy to their side culminated in the seventeenth-century, but thereafter petered out. ${ }^{24}$ Already in the sixteenth century Lutherans had sought to entice the Greek Church to join in a union. These efforts failed, though the correspondence between Martin Crusius and the Patriarchate did result in him receiving the text of the two sixteenth-century Greek chronicles that formed the core of his already mentioned Turcograecia of 1584. The conversion of the Patriarch Cyril Lucaris (1570-1638) to Calvinism brought the competition to a frenzy. ${ }^{25}$ His murder, however, in 1638 effectively ended the Calvinist phase of the competition. Rome remained active throughout the period, but its greatest victory was in Slavic lands, with the Union of Brest in 1596), ${ }^{26}$ rather than in Greece. Finally, in the later seventeenth century the Anglican Church made a go of it. But despite its greater communality with

23 Ibid., p. 109. See ARnaldo Momigliano, « After Gibbon's Decline and Fall », in KuRt Weitzmann (ed.), Age of Spirituality: A Symposium, The Metropolitan Museum, New York 1980, p. 7-16, who points out that Gibbon's disparagement of Christianity would not have created anywhere the furor that it did if it had appeared not in the first installment of his history in 1776, but as part of the whole work when the third installment came out in 1788.

24 In general see Steven Runciman, The Great Church in Captivity: A Study of the Patriarchate of Constantinople from the Eve of the Turkish Conquest to the Greek War of Independence, Cambridge University Press, Cambridge 1968, p. 238-319; and GunNAR HeRInG, Ökumenisches Patriarchat und Europäische Politik, 1620-1638, F. Steiner, Wiesbaden 1968.

25 See Klaus-Peter Todt, « Kyrillos Lukaris », in Carmelo G. Conticello, Vassa Conticello (eds.), La théologie byzantine et sa tradition, vol. II, Brepols, Turnholt 2002, p. 617-658. GEORG HofmAnN, Griechische Patriarchen und römische Päpste. Untersuchungen und Texte, vol. II.1: Patriarch Kyrillos Lukaris und die römische Kirche, (Orientalia Christiana, 15/1), Pont. institutum orientalium studiorum, Rome 1929; CASIMIR EMERAU, «Lucar, Cyrille », Dictionnaire de Théologie Catholique, 9 (1926), col. 1003-1019; and George A. Chatzéantoniou (Hadjiantoniou), Protestant Patriarch: The Life of Cyril Lucaris, 1572-1638, Patriarch of Constantinople, John Knox Press, Richmond, VA 1961.

26 See Bert Groen, Wil van den Bercken (eds.), Four Hundred Years: Union of Brest (1596-1996). A Critical Re-evaluation. Acta of the congress held at Hernen Castle, the Netherlands, in March 1996, Peeters, Louvain 1998. For subsequent unions up to 1698, see MiCHAEL LACKO, " Unionsbewegungen im slavischen Raum und in Rumänien ", in Wilhelm NysSen, Hans Joachim Schulz, Paul WierTz (eds.), Handbuch der Ostkirchenkunde, vol. I, Patmos Verlag, Düsseldorf 1984, p. 269-286. For activity in Rome, see Ingo HeRkLotz, Die Academia Basiliana: griechische Philologie, Kirchengeschichte und Unionsbemühungen im Rom der Barberini, Herder, Rome 2008; and HoFMANN, Griechische Patriarchen, cited in the previous note. For theological developments see GERHARD PODSKALSKY, Griechische Theologie in der Zeit der Türkenherrschaft (1453-1821), C. K. Beck, Munich 1988, p. 117-329. 
Orthodoxy when compared to Lutheranism and Calvinism, its attempt came to naught as well. ${ }^{27}$

Then there was the brute fact that by 1700 European horizons had radically expanded beyond Europe and the Middle East. The treaties of Utrecht and Rastadt in 1713 and 1714 ended the War of Spanish Succession only to set the stage for the great eighteenth-century duel for empire from the Americas to Asia between England and France. Not only the interests of the reading public, but also the producers of literature on travel and geography changed. As Febvre and Martin point, until the mid-sixteenth century French readers seemed almost obsessed with books about the Turks, but in the later part of the century this changed ${ }^{28}$ and by the seventeenth century books on the New World were flooding the market, soon matched by the literature of Catholic missionaries and various travelers and adventurers in Asia. ${ }^{29}$ The Turks and the Greeks had become only a niche in the geographic, religious, and ethnographic interests of the eighteenth-century European educated world.

In the nineteenth century, nationalism and Romanticism brought about a new and intense appreciation of the Middle Ages. Byzantine studies followed, pulled along in the wake of this momentous enthusiasm for all things medieval, but decidedly late. Although one can easily identify important publications in Byzantine studies in the course of the nineteenth century, ${ }^{30}$ Charles Diehl long ago and, separately and more recently, John W. Barker and Peter Schreiner have dated the beginning of the modern professional study of Byzantine philology to the publication of Karl Krumbacher's Geschichte der byzantinischen Litteratur in 1891 and the appearance of the first number of Byzantinische Zeitschrift the next year and then in 1894 of Vizantiyskiy Vremennik. ${ }^{31}$ So it was not until the 1890 s that modern Byzantine studies really took off. Only then did university chairs specifically dedicated to Byzantium begin to be created. ${ }^{32}$

27 See Runciman, The Great Church in Captivity, p. 289-319.

28 See Lucien Febvre, Henri-Jean Martin, Coming of the Book: The Impact of printing 1450-1800, trans. DAVID GERARD, Verso, London 1976, p. 280-282.

29 One can get a sense of this ever-expanding literature from DonaLd F. LACH, Asia in the Making of Europe, vol. III, Book 1: A Century of Advance. Trade, Missions, Literature (with EDWIN J. VAN KLEY), University of Chicago Press, Chicago 1993, p. 301-597 (« The Printed Word»).

30 See, for instance, the works discussed by CHARLES DieHL, « Les études byzantines en France au XIX siècle », in his Études Byzantines, A. Picard et fils, Paris 1905, p. 21-37

31 ID., « Les études d'histoire byzantine en 1905 » in his Études Byzantines, p. 38-106, at 39-40; PETER SChreiner, «Filologia Bizantina », in Marco Buoncore, Ambrogio M. Piazzoni (eds.), La Biblioteca Apostolica Vaticana, luogo di ricerca al servizio degli studi: Atti del convegno, Roma, 11-13 novembre 2010, Biblioteca Apostolica Vaticana, Città del Vaticano 2011 (Studi e testi, 468), p. 49-67, at 50; JoHN W. BARKER (ed.), Pioneers of Byzantine Studies in America = Byzantinische Forschungen 27, Adolf M. Hakkert, Amsterdam 2002, p. XI.

32 On the progress of Byzantine studies from the nineteenth to the twentieth century, I found insightful and informative: PETER CHARANIS, «Some Observations on the Evolution of Byzantine 
To sum up, since the Middle Ages did not end with the Byzantine Empire in 1453, Byzantium as an historiographical construct became inextricably bound with the fate of the Middle Ages in the West. Hence, Byzantium as a recognized distinct area of study did not emerge until the Middle Ages themselves ended in the seventeenth century and educated European society divided the past neatly into ancient, middle, and modern. But even if Byzantine studies, qua Byzantine, can date their origin from the seventeenth century forward, their distinctiveness from other fields of studies often remained fuzzy. For instance, Johann Fabricius's great Biblioteca Graaca, the last volume of which appeared in 1736, treated Byzantine literature as an extension of classical Greek literature..$^{33}$ Indeed, one of the greatest of the seventeenth-century Byzantinists, the aforementioned Leone Allacci, approached Byzantium not as a subject in itself by as a part of the history of Greek Christianity from the Church Fathers to the religious debates of the seventeenth century. One needs to appreciate the significance of the intense competition between Protestants and Catholics over the Orthodox Church for the historical outlook of Europeans well into the seventeenth century. So, in some important respects the medieval world did not end until the end of the seventeenth century. Not completely facetiously therefore have I suggested that Prince Eugene of Savoy and his victory at the Battle of Zenta in 1697 should be commemorated in the historiography of Byzantine studies. The geopolitical revolution in Eastern Europe at the end of the seventeenth century changed how the West viewed not only the Ottomans but also the medieval Greeks. ${ }^{34}$ Edward Gibbon was not the creator, but the most effective popularizer of the subsequent scorn for Byzantium in the Enlightenment, so much so that it was rather late in

Studies since the 1930s ", in CYrIL Mango, OMelJAn PritsaK, Uliana M. PASICZNYK (eds), Okeanos: Essays Presented to Ihor Ševěnko on His Sixtieth Birthday by His Colleagues and Students = Harvard Ukrainian Studies, 7 (1983), p. 95-99; FIONA K. HAARER, «Writing Histories of Byzantium: the Historiography of Byzantine History », in Liz JAmEs (ed.), A Companion to Byzantium, WileyBlackwell, Oxford 2010, p. 9-21.

33 Bibliotheca Grceca: sive notitia scriptorum veterum grcecorum quorumcunque monumenta integra, aut fragmenta edita exstant, tum plerorumque è MSS. ac deperditis, 14 vols, sumptu Christiani Liebezeit, typis Stromerianis-sumtu [sic] viduae Felgineriae, Hamburgi 1708-1728. Starting with vol. 10, Fabricius dealt, as his subtitle put it, "maxime vero de scriptoribus mediae et infimae Graeciae ».

34 And this is not to speak of its eventual effect in the Balkans because it would in time allow states freed of Ottoman domination to study their national histories and Byzantine background. In this regard, see three articles in PAUL STEPHENSON (ed.), The Byzantine World, Routledge, London 2010: Despina Christodoulou, "Byzantium in Nineteenth-Century Greek Historiography », p. 445-461; PAUl STEPHENSON, "Pioneers of Popular Byzantine History: Freeman, Gregorovius, Schlumberger », p. 462-480; and SRĐAN PIRIVATRIć, " A Case Study in the Emergence of Byzantine Studies: Serbia in the Nineteenth Centuries », p. 481-490. 
the nineteenth century that the modern enthusiasm for all things medieval eventually brought in its wake the establishment of professionally institutionalized Byzantine studies. 